\title{
Systematic design of microstructures by topology optimization
}

\section{Sigmund, Ole}

\section{Published in:}

Symposium on Design, Test, Integration and Packaging of MEMS/MOEMS 2003.

Link to article, DOI:

10.1109/DTIP.2003.1286997

Publication date:

2003

\section{Document Version}

Publisher's PDF, also known as Version of record

Link back to DTU Orbit

Citation (APA):

Sigmund, O. (2003). Systematic design of microstructures by topology optimization. In Symposium on Design, Test, Integration and Packaging of MEMS/MOEMS 2003. (Vol. 2). IEEE. https://doi.org/10.1109/DTIP.2003.1286997

\section{General rights}

Copyright and moral rights for the publications made accessible in the public portal are retained by the authors and/or other copyright owners and it is a condition of accessing publications that users recognise and abide by the legal requirements associated with these rights.

- Users may download and print one copy of any publication from the public portal for the purpose of private study or research.

- You may not further distribute the material or use it for any profit-making activity or commercial gain

- You may freely distribute the URL identifying the publication in the public portal

If you believe that this document breaches copyright please contact us providing details, and we will remove access to the work immediately and investigate your claim. 


\title{
DTIP鱼
}

Cannes-Mandelieu, 5-7 May 2003

\section{SYSTEMATIC DESIGN OF MICROSTRUCTURES BY TOPOLOGY OPTIMIZATION}

\author{
Ole SIGMUND \\ TU of Denmark, Lyngby, Denmark \\ Email: sigmund@mek.dtu.dk
}

\begin{abstract}
The topology optimization method can be used to determine the material distribution in a design domain such that an objective function is maximized and constraints are fulfilled. The method which is based on Finite Element Analysis may be applied to all kinds of material distribution problems like extremal material design, sensor and actuator design and MEMS synthesis. The state-of-the-art in topology optimization will be reviewed and older as well as new applications in phononic and photonic crystals design will be presented.
\end{abstract}

